\title{
Trade in Andean Condor Vulture gryphus feathers and body parts in the city of Cusco and the Sacred Valley, Cusco region, Peru
}

\author{
Robert S. R. Williams ${ }^{1 *}$, Jose Luis Jara ${ }^{1}$, Daphne Matsufuiji ${ }^{2}$ \\ and Anahi Plenge ${ }^{2}$
}

${ }^{1}$ Frankfurt Zoological Society and the Andean Condor Working Group - Peru ${ }^{2}$ Clorinda Matto de Turner 305, Urb. Magisterio, Cusco, Peru

*Corresponding author: Rob@szfperu.org

\section{Summary}

The sale of Andean Condor feathers and body parts is undertaken openly in the tourist markets of Cusco and the Sacred Valley. This trade is illegal but there is no enforcement of existing legislation. We visited the main tourist markets of the region to ascertain the extent of the trade, reasons motivating it and value. We found condor feathers for sale in 26 establishments. Feathers were sold singly, decorated and incorporated in handicrafts. Prices ranged from 5 soles for a small body feather to 160 soles for a main primary and we found handicrafts for sale at prices of up to 650 soles (featuring 6 feathers). We were offered a whole condor for sale at a market in Cusco for 2,500 soles. Investigations revealed that there are condor hunters working to supply this trade in both the Cordillera Vilcabamba and Cordillera Vilcanota and that the town of Calca is the base of much of the handicraft production. The trade is mainly based on three uses: alternative healing, shamanic ceremonies and souvenirs. It is crucial that the Peruvian authorities honour their commitments under international conventions and act immediately to stop this illegal trade, which is further threatening a species that is already in a precarious situation.

\section{Resumen}

La venta de plumas y otras partes del cuerpo de Cóndor Andino se lleva a cabo abiertamente en los mercados turísticos de Cusco y el Valle Sagrado. Esta actividad es ilegal, pero no hay cumplimiento de la legislación vigente. Hemos visitado los principales mercados turísticos de la región para determinar el alcance del comercio, y las razones que lo motivan así, como su valor. Encontramos plumas de cóndor en venta en 26 establecimientos. Las plumas se venden por separado, también como decoración o incorporado en la artesanía. Los precios varían desde 5 soles por una pluma de cuerpo pequeña hasta los 160 soles por una primaria principal; también se encontró algunas 
artesanías para la venta a precios de hasta 650 soles (con 6 plumas). También, nos ofrecieron a la venta un cóndor completo en un mercado de Cusco por 2.500 soles. Las investigaciones revelaron que hay cazadores de cóndores que trabajan para suplir esta demanda, tanto en la cordillera de Vilcabamba como en la cordillera de Vilcanota y que la ciudad de Calca es la base de gran parte de la producción artesanal. El comercio se basa principalmente en dos usos: en la medicina alternativa y ceremonias chamanísticas, y como recuerdo. Es crucial que las autoridades peruanas cumplen con sus compromisos bajo los convenciones internacionales y actuar de inmediato para hacer cumplir la ley y detener este actividad ilegal que está amenazando aún más esta especie que de por si se encuentra en una situación precaria.

\section{Introduction}

The Andean Condor Vultur gryphus is considered Near-threatened at a global level (IUCN 2011) and Endangered in Peru (Peru Supreme Decree 034-2004). In all areas where there is reliable information the species is considered to be declining and populations are becoming increasing fragmented. In Peru, approximately 500 condors are estimated to remain in the Andes and coastal areas but the species is undoubtedly declining throughout the country (RW unpublished data). The main cause of the species decline in Peru is probably the systematic legal persecution, including both poisoning and shooting, that was undertaken and encouraged by the Peruvian government during the first half of the $20^{\text {th }}$ Century, especially at Guano Islands along the coast in order to protect the seabird colonies there (Cushman 2003). More recently, illegal but deliberate persecution, lack of food, accidental poisoning, accidental death during traditional ceremonies and hunting for the illegal trade in feathers and body parts have resulted in an apparent ongoing decline in numbers (RW unpublished data).

In Peru, the Andean Condor is legally protected in Peru by Articles 308 and 309 of the Penal Code and Supreme Decree 034-2004. These laws prohibit hunting, capturing, possessing, transporting or trading in the species or its body parts and stipulate that such actions are theoretically punishable by up to four years in prison or up to a year community service. However to our knowledge there has never been a prosecution related to Andean Condors in Peru and the authorities responsible for implementing this have little interest or knowledge of the situation. Consequently illegal animal trafficking is widespread and obvious in Peru and many Peruvians are probably not even aware of its illegality.

This study aimed to evaluate the extent and main locations of sale of Andean Condor feathers and body parts in tourist markets and shops after the lead author observed feathers for sale in various locations. We also make recommendations for a strategy for controlling this illegal 
trade. To our knowledge this is the first report of trade in the species.

\section{Methods}

On 14 and 15 April 2010 a team of 10 people visited all the main tourist markets and shop areas in the city of Cusco and the nearby Sacred Valley. We visited all shops and market stalls in these areas, totalling just over 200 establishments (the exact number is hard to define as it is often hard to distinguish different establishments in markets) and noted the presence of condor feathers or body parts for sale. If Condor derivatives were for sale we then attempted to obtain as much information as possible about the price, origin, use of the feathers and the level of awareness of the shopkeeper of the legislation and the conservation status of the condor, through the use of a semi-structured questionnaire (Appendix 1). The 7 simple questions were memorised and we remembered the answers received and recorded these after the visit. Frequently shopkeepers became suspicious and refused to answer after a few questions. Where possible photos were taken of the feathers on display.

\section{Results}

In total we visited more than 500 points of sale (market stalls and shops) and found Condor feathers and body parts openly for sale in 26 different establishments. We observed a total of at least 344 Andean Condor feathers for sale including: 36 Primary feathers, 58 Secondary feathers, 7 Tertial feathers, 9 tail feathers, as well as 4 wing bones, 3 complete wings and two whole dead condors (Table 1). In some shops it was not possible to correctly count all feathers and we also observed Andean Condor feathers in workshops and back rooms where we could not access to count. The numbers here are an underestimate of the total availability of Andean Condor feathers in the region. We estimate that what we observed must have originated from at least 8 different individual condors, based on number and position of feathers and age of the birds they were taken from.

Table 1. Number of Andean Condor (Vultur gryphus) feathers and body parts observed for sale on 14th and 15th April 2010 in Cusco and the Sacred Valley

\begin{tabular}{lll}
\hline Type of Feather & As single feathers & In Handicrafts \\
\hline Primaries & 30 & 6 \\
Secondaries & 22 & 14 \\
Tertials & 7 & 0 \\
Tail & 9 & 0 \\
Greater Coverts & 73 & 27 \\
Others & $100+$ & 56 \\
\hline Total Feathers & 241 & 103 \\
\hline Wing Bones & & 4 \\
Whole wings & 3 & \\
Whole Condors & 2 & \\
\hline
\end{tabular}


We found that the main areas that sold Condor feathers are:

Pisac. The sale of Condor feathers was detected in seven shops, but not in the market stalls (though we have previously seen decorated Condor feathers for sale on stalls). It was concentrated on the south side of the market and in the street to the southeast. This is undoubtedly the main point of sale of Condor Feathers to tourists with shops with up to 97 feathers on sale singly, decorated, in wands with crystals and Palo Santo handles, or in dream catchers. The Shamanic and alternative healing industry in Pisac is undoubtedly a large factor in the promotion of the use of condor feathers. The availability of Condor feathers in local stores has increased dramatically in the last year based on our previous visits to the area and the opinion of several tour guides interviewed.

Cusco. We found condor feathers for sale in shops (Calle Triunfo and San Blas) and tourist markets (on Avenida El Sol, the market at Calle Plateros 334 and on Calle
Triunfo) and in the local market of San Pedro. Alternative healers and shamans in the San Blas area and on Calle Triunfo also use feathers.

Ollantaytambo. Sale here was only in a few shops near the handicraft market and one on the main square.

Huasao. This village is famous for its shamans. Three Shamans that we visited had or used Condor feathers in their healing ceremonies. The degree of use and the need for replacement of these feathers is unknown though one Shaman commented that he did not believe in this and only used condor feathers on request.

Calca. Whilst we found no feathers for sale in the town, this village has two workshops that prepare handicrafts with Condor feathers and supply the market at Pisac.

Prices for Condor products varied from 5 soles for a single small body feather to 150 soles for a main primary feather, known locally as the "guia" (guide) and up to 650 soles for "dream catchers" incorporating 6 condor feathers (see Table 2 for full details of prices).

Table 2. Prices of Single Condor Feathers in local markets and tourist markets and shops. Prices in local currency - Nuevo Sol and US Dollar equivalent given in parentheses).

\begin{tabular}{llll}
\hline Feather & Local Market Price & $\begin{array}{l}\text { Minimum Tourist } \\
\text { Price }\end{array}$ & $\begin{array}{l}\text { Maximum Tourist } \\
\text { Price }\end{array}$ \\
\hline Main Primary ("guia") & 40 soles & 100 soles & 150 soles \\
& (US\$ 14.13) & (US\$ 35.33) & (US\$ 53.00) \\
Other Primary & $15-40$ soles & 70 soles & 100 soles \\
& (US\$ 5.30-14.13) & (US\$ 24.73) & (US\$ 35.33)
\end{tabular}




\section{Table 2 continued}

\begin{tabular}{|c|c|c|c|}
\hline Feather & Local Market Price & $\begin{array}{l}\text { Minimum Tourist } \\
\text { Price }\end{array}$ & $\begin{array}{l}\text { Maximum Tourist } \\
\text { Price }\end{array}$ \\
\hline Secondary/Tail Feather & $\begin{array}{l}\text { 20-30 soles } \\
\text { (US\$ 7.06-10.60) }\end{array}$ & $\begin{array}{l}50 \text { soles } \\
\text { (US\$ 17.66) }\end{array}$ & $\begin{array}{l}90 \text { soles } \\
\text { (US\$ } 31.80)\end{array}$ \\
\hline Tertial Feather & $\begin{array}{l}20-30 \text { soles } \\
\text { (US\$ 7.06-10.60) }\end{array}$ & - & - \\
\hline Tail Feather & $\begin{array}{l}10 \text { soles } \\
\text { (US\$ } 3.53)\end{array}$ & - & $\begin{array}{l}85 \text { soles } \\
(\text { US\$ } 30.03)\end{array}$ \\
\hline Greater Covert & $\begin{array}{l}5 \text { soles } \\
\text { (US\$ 1.76) }\end{array}$ & $\begin{array}{l}10 \text { soles } \\
\text { (US\$ } 3.53)\end{array}$ & $\begin{array}{l}15 \text { soles } \\
\text { (US\$ } 5.30)\end{array}$ \\
\hline Other small feathers & $\begin{array}{l}5 \text { soles } \\
(\text { US\$ } 1.76)\end{array}$ & - & $\begin{array}{l}10 \text { soles } \\
\text { (US\$ } 3.53 \text { ) }\end{array}$ \\
\hline
\end{tabular}

Prices varied greatly on the location of the shop and the apparent nationality of the person asking. The greatest difference was based on location; local markets that cater for mainly Peruvians were much cheaper and are considered to likely be a source of feathers for shop keepers and stall holders who then sell to tourists at higher prices. The main local market trading in Andean Condor feathers and body parts is the San Pedro Market in Cusco. Here we were offered an entire condor for collection the following day for the cost of 2,500 soles.

It is clear from this pricing that a whole Andean Condor is therefore worth approximately 9,000 soles (US\$ 3,180) at maximum tourist prices and approximately 2,500 soles (US\$ 880) at local market prices.

The main forms of sale of Condor feathers and body parts are as:

Single undecorated feathers. These were sold as souvenirs, for use in "Pago a la Tierra" ceremonies or for their "healing" powers, said to remove bad energies and heal a variety of ailments.Especially valuable are the longest primary feathers [primaries 1-6 but especially primaries 3 and 4] or "Guias" as they are known. Prices ranged from 5 soles to 150 soles. In one case a "Guia" was offered for 224 soles (US\$ 79.15) that would come "charged" with healing energy and even a curse to ensure that it would not be detected in customs

Single decorated feathers. Two of these were seen; 1 decorated with images of an Inca for sale alone and 1 with a scene from Machu Picchu which was framed. The price unframed was approximately the same as a single feather at 70 soles (US\$ 24.73) and framed was 150 soles (US\$ 53.00).

Shamanic wands with Condor feathers. These were found in tourist markets 
in Cusco and in shops in Pisac and Ollantaytambo. They were generally made from Palo Santo Bursera graveolens wood with one or several Andean Condor feathers, a clear crystal inserted in the base of the handle and leather strapping. They are purported to help clean bad energies and are sold in stores that focus on quasishamanic healing therapies and products. Prices ranged from 120 to 150 soles (US\$ 42.40-53.00).

\section{Dream Catchers with Condor feathers.}

These were found for sale in many places but were most common in Pisac. They varied in size and included from 1 to 6 Condor feathers and in price from 80 soles for a small one with 1 small feather to 650 soles (US\$230) for a three-tiered large one with 6 feathers.

Condor Bone Flutes. Four of these were found for sale is a market stall off Calle Plateros 334 in Cusco and were for sale at 120 to 145 soles each (US\$ 42.40 to US\$ 51.23). They were made from wing bones, apparently the humerus and radius.

\section{Ceremonial pipes with Condor feathers.}

These were observed only in one shop in Ollantaytambo where three were on sale, each one had one condor greater covert as part of the decoration. Prices were 60-100 soles (US\$21.20-35.33) per pipe.

\section{Lucky charm bracelets with Condor} feathers. These were seen in Huasao where a Shaman would give one to each customer. They were simple bracelets with a single condor body feather attached.

The turnover rate of feathers is unknown.
RW made an effort to revisit some shops three months later but could not identify with certainty whether feathers were new or the same, some noticeable pieces were absent and presumed sold. Given this and the fact that many shopkeepers in main tourist markets are investing in condor feathers we assume that trade in these must be fairly reliable.

\section{Sourcing of Condor Feathers}

All retailers identified the feathers as belonging to Condors. In one case they even tried to pass off Black-chested Eagle Geranoaetus melanoleucus and Egret Egretta sp. feathers as belonging to Condor. No retailer tried to deny the identity of the feather upon questioning.

The conversations with sales people led us to identify reported source areas for the feathers as:

Apurimac Canyon. Feathers for sale in local markets were reported to originate from there.

Salcantay massif. A shaman at Huasao told of a hunter who killed condors to order near Salcantay.

Cordillera Vilcanota. Most of the retailers in the Sacred Valley cited the Cordillera Vilcanota as the source.

Chivay in Arequipa. One shop-owner in Pisac reported sourcing them directly from Chivay in the Colca Canyon.

\section{How they obtain the Condor feathers}

When asked how they collect the feathers we received a range of answers from 
admission that the Condors were killed (5 people replied openly about this), sometimes accompanied with explanations like they only kill old ones or dying ones, or even that male condors only live one year so there are lots, or that they do a Pago a la Tierra ceremony before they kill the condor which makes it alright to do so. Two people admitted that they were condor hunters who killed the condors for commercialization of the body parts; apparently condors are obtained by shooting or poisoning a carcass. Other people responded that people collected moulted feathers in the mountains or at roost and nest sites. One person replied that they caught condors and extracted some feathers and let them go again.

\section{Perceived Legality of Selling and Exporting Condor Feathers}

When asked if it was legal to sell Andean Condor feathers, of 19 people asked, 9 people stated that it was, 6 said it was not, 3 failed to reply and 1 said they did not know. When asked if they could be taken out of Peru legally, 7 people said yes, 5 said it was OK but you had to hide them, wear them or have them in a handicraft and 1 person said they did not know.

\section{Awareness of Andean Condor Conservation Status}

When asked if they knew if the Andean Condor was rare or threatened with extinction, 1 person admitted it was endangered, 1 said it was common and not endangered, 4 people failed to reply and 3 said they did not know.

As we progressed with the questions some people became suspicious, sometimes hiding feathers and in one case becoming aggressive. It is clear that most sellers know that this is somewhat illegal, perhaps not being fully aware of the possible penalties. The fact that five sellers advised us to hide, wear or incorporate feathers in handicrafts in order to take them out of the country and that one offered feathers with a spell to ensure they would not be detected in customs also demonstrates an awareness of the illegality of exporting them from Peru and importing them into other countries.

\section{Cultural and mystical reasons for condor body part trade}

Much of the trade in Condor feathers can be associated with an increase in mystical tourism and alternative medicine and healing which is promoting the use and commerce of Andean Condor feathers. Many sellers told us of the healing and cleansing powers of the feathers; the feathers apparently capture the energy of the winds of the Andes and thus can absorb negative energies when passed over a person. Especially in Pisac and the shops and markets of Cusco this seems to be the prime motive for sellers and presumably purchasers of Condor feathers. One shaman in Huasao also told us that the use of Condor feathers is nonsense and requires a cleaning afterwards but he was willing to do it if people asked for it. 
It also appears that local guides are promoting the use of Condor feathers in Pago a la Tierra ceremonies. This would seem to be motivated by the percentage of the purchase price that they receive, as local people do not traditionally use Condor feathers in Pago a la Tierra ceremonies; it is actually contradictory to traditional beliefs that the Andean Condor was a messenger and sacred. This use is obviously unsustainable as the feathers are burnt and so new feathers are used for each ceremony.

It seems the promotion of mystical tourism and quasi-shamanic healing in the region is strongly contributing to the trade in Condor feathers. This is reflected by the contents of a book by Nina Linares (Linares 2008) who on pages 86 and 87 writes of the Andean Condor feather:

"We could say these are 'master feathers' that guide the therapist to highly expanded levels of intuition and vision."

"...the energetic specialty of these feathers is to expand the qualities of the Third Eye"

"...every Condor feather that comes into your hands connects the therapist with the energy of those great natural cosmic antennas that are mountains."

"As they fly very high the feathers of this bird have a very high vibration and are very powerful."

She goes on to describe the sacred valley as the best place to obtain Andean Condor feathers from local artisans in the local markets.

\section{Conclusions and Recommendations}

Despite being illegal the trade in Andean Condor body parts continues openly in major tourist areas that are well patrolled by police. It is clear that there is a lack of awareness amongst authorities of the conservation and protected status of the Andean Condor and a lack of capability and political will to enforce wildlife protection legislation in the region.

Whilst the sale of Andean Condor feathers is not a primary product or income source for any of the people we met, it is clear that it has a commercial value that is stimulating an illegal commercial chain and causing Andean Condors to be hunted.

Beliefs in quasi-shamanic mystical healing and curing are largely stimulating the local commerce in Andean Condor body parts, especially feathers. The publication of books extolling the virtues of the Andean Condor feather and citing the Sacred Valley as a source of feathers is especially worrying and action should be taken against the authors and publishers for promoting wildlife crime.

Action is urgently needed to tackle this situation and stop the sale of condor feathers in Cusco. We recommend the following actions be taken:

1. The implementation of an educational campaign using bilingual (Spanish and Quechua) leaflets aimed at local people informing them that possessing, selling or using Andean Condor feathers is illegal and punishable by prison of up to 7 years and fines. 
2. An education campaign targeted at national authorities responsible for control of trade in animal parts (Police, Ecological Police, Prosecutors office, Judges and the wildlife authority of the Ministry of Agriculture) to raise awareness of the issue, increase capability on the ground to identify Andean Condor feathers and body parts and act on this. This will be supported by logistical support for inspections and confiscations.

3. An immediate campaign of confiscation of Andean Condor feathers from all shops and markets. This will result in a financial loss for the shopkeepers and we anticipate will reduce their willingness to purchase more feathers in the future.

4. Follow up campaigns of confiscation and legal proceedings against people who continue to sell Andean Condor feathers with inspection visits several times a year until the trade has ceased.

5. Investigation of reports of Condor hunting and legal follow up if these can be traced.

6. A campaign to educate tourists to not buy Andean Condor feathers using posters in restaurants, bars and hotels and banners in major airports. This should be accompanied by warnings on foreign embassy websites, travel sites and supported by local and national tourism promotion and regulation bodies (PromPeru and Ministry of Tourism)
7. Promotion of the Andean Condor as a symbol of Cusco and potential tourist attraction. We propose that the regional government of Cusco nominate the Andean Condor regional bird.

The above activities will be included in the national condor conservation strategy currently in development and when approved by the national and regional authorities will generate institutional commitments from the relevant authorities and NGOs to undertake these actions. Annual monitoring of these activities by the Peruvian Andean Condor Working Group will ensure enforcement.

Whilst the trade in Andean Condor feathers presents an interesting research opportunity we anticipate being able to stop the trade very quickly once the national strategy is adopted (hopefully in November 2011) and as such there should be no trade to study. We will ensure all confiscated feathers and body parts are well documented and kept for further study including genetic studies to identify numbers of individuals involved and make population estimates, analysis for lead and possibly other pollutants. We will also document the full extent of the trade after its cessation.

Many details of the trade remain undocumented and we recognise the importance of knowing turnover rate of feathers and numbers of birds being killed in order to better assess the impact on the species. However, it is clear that the species is in such a precarious situation 
that any trade should not be countenanced. In a future publication we will attempt to undertake some population modelling of the species in Peru including various trade scenarios.

\section{Acknowledgements}

We thank the other FZS Peru staff and volunteers and tourism guides who took part in the surveys. An anonymous reviewer made helpful comments and suggestions which improved the manuscript and strategy.

\section{References}

Peruvian Government (2004) Supreme Decree 034-2004. Categorización de Especies Amenazadas de Fauna Silvestre y Prohíben Su Caza, Captura, Tenencia, Transporte o Exportación con Fines Comerciales. El Peruano, 22 de septiembre de 2004

Cushman, G.T. (2003) The Lords of Guano: Science and the Management of Peru's Marine Environment, 1800-1973. PhD Thesis, The University of Texas at Austin.

Linares, N. (2008) Masaje Áurico con plumas de poder. Buenos Aires, Argentina: Editorial Devas.

\section{Appendix 1: Questionnaire used}

1. What type of feathers are these (indicating various species including condor)?

2. Where do they make these (if handicrafts)?

3. Where do they get the feathers from?

4. How do they get the feathers?

5. Can I take them to my country (if "foreigner" asking)/can I export them (if "Peruvian" asking)?

6. Is it legal to sell them?

7. Do you know if the condor is protected or threatened?

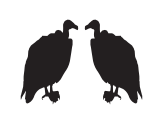




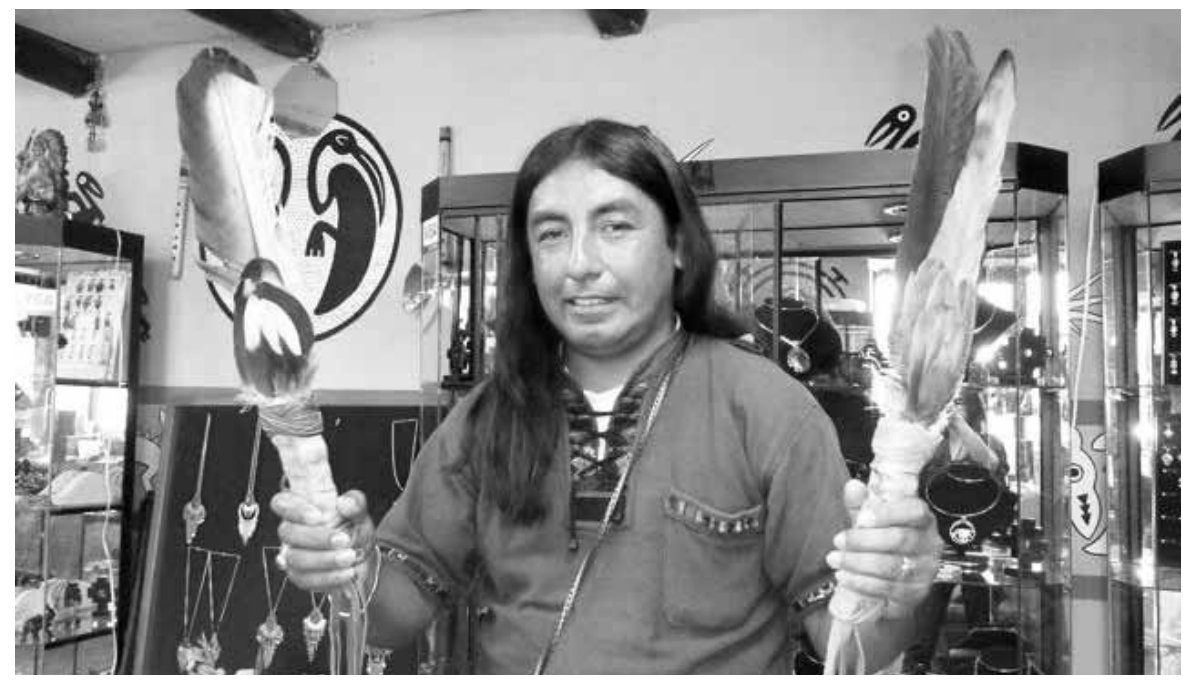

Photo 1: Shamanic wands with Andean Condor (Vultur gryphus) feathers for sale in Pisac $15^{\text {th }}$ April 2010.

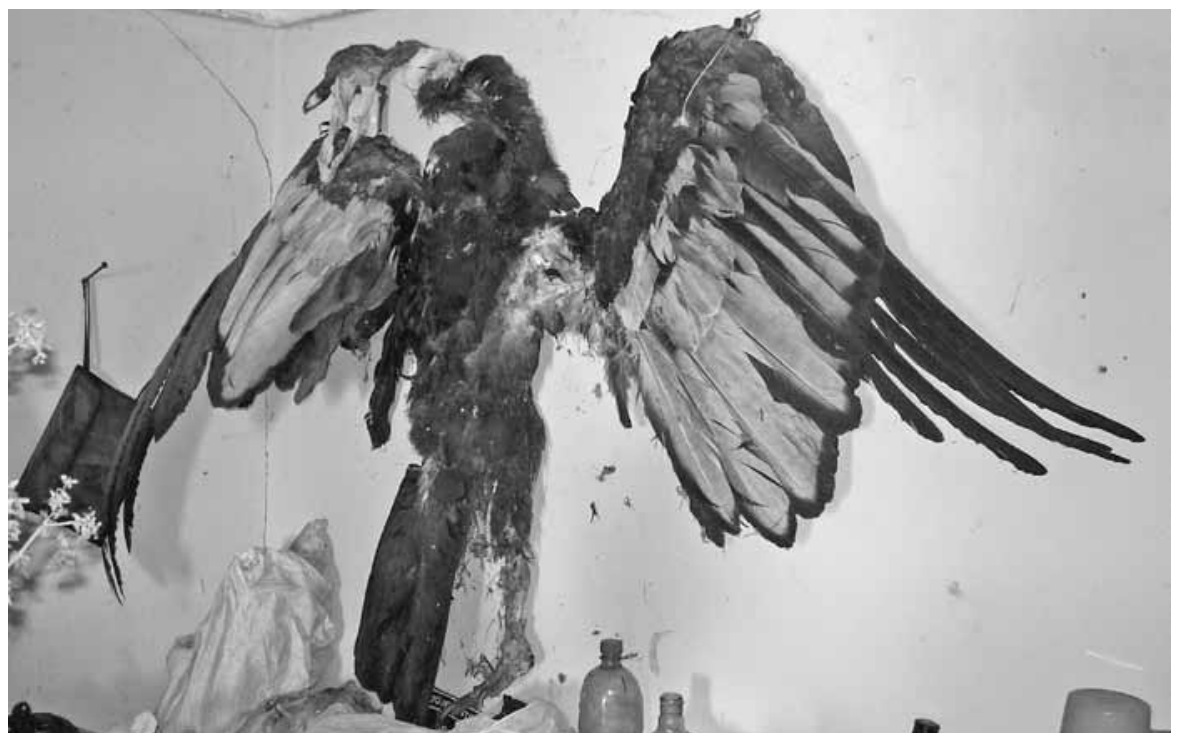

Photo 2: Andean Condor (Vultur gryphus) skin in Shaman's house, Huasao, Cusco, $14^{\text {th }}$ April 2010. 